\title{
The Securing a Claim in the Context of Sustainable Development: An Evaluation of the Latvian Experience
}

\author{
By Andrejs Gvozdevičs ${ }^{1}$
}

\begin{abstract}
Article 6 of the Convention for the Protection of Human Rights and Fundamental Freedoms provides for the right of everyone to a fair and public hearing by an independent and impartial tribunal established by law. An important guarantee, such as the enforcement of a court judgment, is also enshrined in human rights theory and practice, as unenforced judgments pose a threat to legal stability, which is one of the fundamental basis for the sustainable development of society. The institute of law of the securing a claim serves in cases where execution of the future judgment may be impossible or made substantially more difficult. The aim of the research is to study the legal framework, which determines the regulations of the securing a claim in Latvia in order to make proposals for enhancement of the legal framework. The research deployed descriptive, analytical and deductiveinductive methods as well as the methods of interpretation of legal norms. Using these methods, legal acts, views of legal scientists and case law were reviewed and analyzed, and subsequently conclusions and recommendations were made. Analyzing the development of the securing a claim it can be admitted that this institute of law in Latvia has problems as the application of the securing a claim in court practice within the framework of limited adversarial and dispositivity principles, as well as shortcomings in the theoretical foundations of the securing a claim which are based on the findings of legal scientists of the last century. As a result of the research, the author drew the conclusions, that Latvia does not make sufficient use of the long-standing successful procedural solutions for securing a claim in others states, such as court mortgages, bank guarantee or mortgage of the plaintiff to secure the defendant's losses, defendant's protection letter to protect against unjustified securing a claim, a possibility to secure a claims which are not financial in nature and many more that can make legal regulation of the securing a claim more modern and effective.
\end{abstract}

Keywords: civil proceeding, legal stability, securing a claim, sustainable development of law

\section{Introduction}

Sustainable societal development is ensured by a qualitative and effective legal framework. The aim of the research is to study the legal framework, which determines the regulations of securing a claim in Latvia in order to make proposals for enhancement of the legal framework. Article 6 of the Convention for the Protection of Human Rights and Fundamental Freedoms provides for the right of everyone to a fair and public hearing by an independent and impartial tribunal established by law (Convention for the Protection of Human Rights and Fundamental Freedoms, 1950). The right to a fair trial is also guaranteed by Section 92 of the Constitution of the Republic of Latvia, stipulating that "everyone may defend his or her rights and lawful interests in a fair court" (the Constitution of the Republic of Latvia, 1922). An important guarantee of the right of a 
person to fair trials is the enforcement of a court judgment, as unenforced judgments pose a threat to legal stability, which is one of the fundamental bases for the sustainable development of society. The institute of the law of securing a claim serves in cases where execution of the future judgment may be impossible or made substantially more difficult. Thus, securing a claim as the institute of law serves the idea of sustainable development, as it guarantees the protection of rights and interests of the persons, including the observance of human rights, ensuring the economic and social stability of society. The institute of securing a claim in Latvia is regulated by Chapter 19 of Civil Procedure Law, which entered into force on March 1, 1999 (Civil Procedure Law, 1999). Since the entry into effect of the Civil Procedure Law, the provisions on the securing a claim have been amended and supplemented sixteen times. The aim of the research is, among other things, to determine whether these amendments to the law eventually made the institute of securing a claim an efficient means of procedural protection. Considering that the proceeding of securing a claim starts in circumstances where the adversarial and dispositional principles are limited and the defendant has no opportunity to present his explanations or objections to securing a claim it is very important if the legal framework provides for a balance between the interests of both parties. The parties to the proceedings must be convinced that the legal framework ensures the fairness, predictability and certainty of the legal system. Legal stability requires that similar cases be resolved in a similar manner on the basis of the principle of fairness, and it is important that it is not the result of the legal assessment but the similarity of the legal basis (motives) (Esser, 1970). The European Court of Human Rights has also repeatedly stated in its judgments that: the principle of legal stability, which is an integral part of a judicial state and the right to a fair trial (ECHR Judgement, 2006). A legal framework of the securing a claim can be considered effective if it really ensures the enforcement of the judgment for the plaintiff, and protects the defendant from the damage caused by the unjustified security a claim. The research has analysed the experience of Latvia in the development of securing a claim in the context of the sustainable development of this institute of law.

\section{Research}

By paraphrasing the definition of the rights given by the German philosopher Immanuel Kant - that rights are the power, which can delimit the arbitrariness of one individual from the arbitrariness of another individual on the grounds of general law of freedom (Kant, 1796), one might argue that securing of the claim is the means, which delimits the arbitrariness of one individual from the arbitrariness of another individual until the moment when the court judgment enters in effect. The purpose of securing of the claim is to find optimum and just compromise between the procedural rights and interests of the plaintiff and the defendant.

In the legal system of the Republic of Latvia institute of law as securing a claim is known since the 1914 Civil Procedure Regulations, which were effective in the Republic of Latvia, based on the Law of the Republic of Latvia "Temporary regulations on the courts of Latvia and procedure of prosecution" of December 6,1918, pursuant to which Latvian courts had to operate according to the local Russian laws, which were effective in the current territory of Latvia until October 24, 1917 (Bukovskis, 1933), and specified the procedure 
of the securing a claim to allow the plaintiff to gain satisfaction in the case of satisfying of the claim. In 1938 the Civil Procedure Law came into effect in Latvia, where Section 174177 of the Chapter 6 "Ancillary procedures" stipulated the rights of the plaintiff to submit request for the securing a claim, compliance with which depended on the magistrate, except for the securing a claim based on a duly endorsed bill or protest bill, the magistrate was not entitled to refuse such requests (Konradi, Zvejnieks, 1939).

On October 14, 1998 the Saeima of the Republic of Latvia adopted the new Civil Procedure Law, which entered in effect on March 1, 1999, and is still valid to the date with many amendments (Civil Procedure Law, 1999). Until the entering in effect of the new Civil Procedure Law, the civil matters in Latvia were regulated by the Civil Procedure Code, which had been adopted on December 27, 1963, in which, after restoration of the independence of Latvia, several amendments and additions had been made within the framework of the judicial reform, which made it more corresponding to the new reality and contemporary requirements (LPSR Civilprocesa kodekss,1963). The Civil Procedure Code of the Soviet Latvia defined the securing of the claim as an aggregate of procedural actions, which are undertaken by the court to guarantee timely and real execution of the judgment (Rozenbergs, Brigis, 1978). Section 137 of the Civil Procedure Code of the Soviet Latvia stipulated that the court or judge by the request of the persons participating in the case or by its or his own initiative may undertake measures to secure the claim. Securing the claim shall be permitted at any state of adjudication of the case, but, without it, execution of the court judgment may become encumbered or impossible, while Section 168 of the Civil Procedure Code stipulated that means for securing of the claim may be attachment of property or sums of money belonging to the defendant and situated with him or other persons, prohibition on the defendant from committing certain acts (LPSR Civilprocesa kodekss, 1963). Definition of securing of the claim of the Civil Procedure Code is very similar to the definition of securing of the claim of the currently applicable Civil Procedure Law, except for regulation that the court is entitled, at its own initiative, to secure the claim, since that would contradict the adversarial principle introduced in the Civil Procedure Law.

Paragraph 1 of Section 137 of the Civil Procedure Law stipulates that securing of the claim may be applied in material claims, if there are grounds to believe that execution of the court judgement in the case might become encumbered or impossible (Civil Procedure Law, 1999). The means for securing of the claim shall be specified in the application for securing of the claim. Securing of the claim shall be permitted only in material claims. Securing of the claim is permitted at any stage of the proceedings, as well as before filing the claim with the court. Such definition of securing of the claim remains unchanged from the moment of entering in effect of the Civil Procedure Law.

By reforming the applicable Civil Procedure Law in accordance with the Operating strategy of the Ministry of Justice 2018-2020, which contains the finding that "in non-material claims the Civil Procedure Law lacks a comprehensive temporary protection regulation" (Ministry of Justice, 2018), in 2021 the Ministry of Justice of the Republic of Latvia established that "currently Latvia is actually the only country in the European Union, which lacks comprehensive temporary protection regulation in civil disputes" (Annotation of the amendments to the Civil Procedure Law, 2021), because since the moment of entering in effect in 1999 the Civil Procedure Law did not provide for securing of the claim 
in non-material claims. As a result, on April 20, 2021 the Civil Procedure Law was supplemented with Paragraph 2 of Section 137, which stipulates that temporary protection may be applied in material or non-material claims, if there is reason to believe that the rights of the plaintiff are being infringed or may become infringed until the judgment enters in effect, and if application of temporary protection is necessary to prevent significant damage (Civil Procedure Law, 1999). The basis and purpose of temporary protection are closely related to the understanding of the definitions "harm" and "delict". The understanding of the concept of the delict is related to Article 1635 of the Civil Law: every delict, that is, every wrongful act per se, as a result of which harm has been caused (also moral injury) shall give the person who suffered the harm therefrom the right to claim satisfaction from the infringer, insofar as he or she may be held at fault for such act (The Civil Law, 1992). It follows, at the same time, that damage may be caused to both pecuniary and non-pecuniary interests. As shown, securing of the claim and temporary protection are related legal institutions, therefore, basically the same principles shall be used in application thereof, with the only difference that securing of the claim is applied only in material claims, while temporary protection is applied both in non-material and material claims. The Civil Procedure Law of Latvia does not provide for classification of claims, except for division into material and non-material claims, while the court practice follows the legal doctrine findings that "in an claims for recognition, the court does not order the defendant to take an action, but the effect of the court opinion is that a new action with enforcement effect may arise on the basis of that opinion" (Bukovskis, 1933), and does not use the procedure of the securing of a claim for claims of the recognition. Definition of the temporary protection fails to provide a clear notion as to whether the recognition claims would be subject to temporary protection, therefore, the answer to this and other issues related to temporary protection, such as the court's right to determine the plaintiff's counter obligations, the simultaneous application of the temporary protection and securing a claim, is expected soon from solutions and interpretations of the case law. Section 138 of the Civil Procedure Law provides for seven means for securing of the claim, namely: seizure of movable property and monetary funds; entering of a prohibition notation in the register of the respective movable property or any other public register; entering of a notation regarding the securing of a claim in the Land Register or Ship Register; arrest of a ship; prohibition for the defendant to perform certain actions; seizure of those payments which are due from third persons, including monetary funds in credit institutions and other financial authorities; postponement of enforcement activities (Civil Procedure Law, 1999). In turn, in accordance with Section 138.1 of the Civil Procedure Law there are five temporary means of protection, namely: pledging of movable property, entering of a prohibition notation or other notation in a public register; prohibition for the defendant to perform certain actions or an obligation for the defendant to perform certain actions within a certain term, postponement of enforcement activities and temporary regulation of the disputed relations (Civil Procedure Law, 1999). Despite of the large number of applicable means available, there are some problems with the effectiveness of some means for securing of the claim. For example, pursuant to Paragraph 5 of Section 138 of the Civil Procedure Law, if the subject-matter of an action is a monetary claim, then such claim shall be secured with immovable property by entering a pledge rights notation in the respective immovable property division of the Land Register (Civil Procedure Law, 
1999). On the other hand, according to the case law, a creditor in whose favour a claim has been secured by a court does not become a secured creditor within the meaning of the Insolvency Law and does not enjoy any advantage over other creditors (Augstākās tiesas Senāta lēmums, 2011), since Paragraph 5 of Section 63 of the Insolvency Law states that the judgment of the court proclaiming insolvency proceedings of a legal person is the grounds for revoking the securing of claims in accordance with the procedures laid down in the Civil Procedure Law (Insolvency Law, 2010 ). Also, in accordance with Paragraph 5 of Section 134 of the Insolvency Law, the judgment of the court announcing insolvency proceedings of a natural person shall be the grounds for revoking the securing of claims in accordance with the procedures laid down in the Civil Procedure Law (Insolvency Law, 2010). Therefore, deficiencies of the right of pledge included in the means for securing of the claim are established, when the right of pledge is perceived only in terms of its procedural application, but ignoring its material legal scope, as a result of which such means for securing of the claim fail to serve the purpose of securing of the claim, creating risks of infringement of personal rights. Such a conflict of laws remains unresolved.

Paragraph 2 of Section 139 of the Civil Procedure Law stipulates that "an application for securing a claim before an action is brought shall be submitted to the court in which the action regarding the claim sought to be secured is to be brought" (Civil Procedure Law, 1999). Whereas, Paragraph 3 of Section 139 of the Civil Procedure Law stipulates that "upon satisfying an application for securing a claim before an action is brought, a judge shall determine a time period for the plaintiff within which he or she must submit a statement of claim to the court or permanent arbitration" (Civil Procedure Law, 1999). Thus, the civil procedural regulations of Latvia do not provide for the possibility to ask the court to secure the claim, if it is essentially planned to be filed with court of another state, including a court of a member state of European Union.

Pursuant to Paragraph 1 of Section 140 of the Civil Procedure Law, a decision on an application for securing a claim shall be taken by a court or a judge not later than the day following receipt thereof, without giving prior notice to the defendant and other participants in the case, or, if the application has been submitted together with the claim application - after initiating of the proceedings (Civil Procedure Law, 1999). Pursuant to Paragraph 1 of Section 131 of the Civil Procedure Law, upon receipt of a statement of claim in a court, a judge shall, within ten days make a decision to initiate proceedings, or to refuse to accept the statement of the claim, or to leave the statement of the claim not proceeded on (Civil Procedure Law, 1999). This means that the court in Latvia can adjudicate the application for securing of the claim even on the eleventh date of receiving thereof. Pursuant to Paragraph 2 of Section 140 of the Civil Procedure Law, a decision on an application for temporary protection shall be taken by a court or a judge, without holding a court hearing and without giving prior notice to the participants in the case, or, if the application has been submitted together with the claim application - after initiating of the proceedings, but, if the court finds it necessary to examine additional circumstances, the application shall be decided at the court hearing within 15 days since receiving thereof, but, if the application has been submitted together with the claim application - after initiating of the proceedings, by summoning the participants in the case (Civil Procedure Law, 1999). In the process of securing a claim, speed of court decision is important to ensure a surprise effect that will prevent the debtor from spending, concealing or disposing 
of his assets or disposing of them below their value or in an unusual amount or performing other unusual actions. Notwithstanding the restriction of adversarial proceedings and, to a certain extent, of the principle of dispositivity, at least at the initial stage of the proceedings of the securing a claim, such restrictions have a legitimate aim, namely the protection of the rights of individuals, which is not possible without enforcement of the court judgment. That is why such procedural terms for the court to examine an application for securing of the claim or temporary protection cannot be considered proportionate and corresponding to the purpose of securing of the claim, namely: to enforce the judgment. Pursuant to Paragraph 1 of Section 140 of the Civil Procedure Law, when deciding on the matter of securing of the claim, the court or the judge shall take into account prima facie formal legal grounds and proportionality between legal interests of the parties (Civil Procedure Law, 1999), which is an important guarantee of the law for the purpose of respecting the rights and interests of the defendant, especially in the cases when application for securing of the claim or temporary protection is being adjudicated in the absence of the parties. At present, the Civil Procedure Law and the case law have developed sufficiently clear criteria for assessing the prima facie formal legal basis and proportionality. On the other hand, regarding the second criterion for assessing the securing of a claim, namely that the enforcement of a judgment may become difficult or impossible without securing of the claim, neither the Civil Procedure Law nor the case law provide any clarity. This criterion of securing a claim is assessed subjectively by the courts, making the securing or dismissal of a claim at the discretion of a judge, that is contrary to the principle of legitimate expectations and opinion embedded in the legal science that civil proceedings are a statutory procedure for the settlement of matters, which has to be complied with by the court and parties, when verifying civil rights of the parties in claim proceedings and in special proceedings (Bukovskis, 1933). This may pose risks to the protection of the plaintiff's interests when the court assesses the adequacy and reliability of the evidence of the impossibility or inconvenience of enforcing the judgment in accordance with the principles of evidence assessment adopted in the proceedings. In order to avoid such risks, in case law should apply the legal doctrine that the standard of proof in the application of temporary protection measures and securing of the claim is higher than at the initiation of proceedings, but lower than in adjudication of the case based on merits, but the burden of proof exists and must be realized at least to a reasonable degree of credibility with the reasonably possible evidence at this stage (Pētersone, 2010). If the procedural law, of course, just like any other law, fails to create a clear and specific answer as to how the judge should proceed when adjudicating the procedural matter, then the judge shall make the decision, based on legal feeling and seek justification afterwards. The German law scientist G. Radbruch describes this understanding as follows: the means of interpretations are selected only after the outcome has already been established, in reality the so called means of interpretation only serve to justify what has already been established before, retrospectively using a text and creatively supplementing this text, and regardless of how this creative addition would sound, this or any other means of interpretation - a decision in a similar case or a decision in a different case - is at such state of readiness that all that remains is to justify it. Thus, interpretation is the outcome of the outcome (Radbruch, 1964). One may agree to the legal doctrine that the purpose of any procedural institute, is to ensure that the court adopts an essentially correct judgment (Baumbach., Lauterbach., 
Albers., Hartmann, 2007). An essentially correct decision in the matter of securing of the claim is a court decision that ensures enforcement of the sentence, given the existence of evidence-based doubts, that the enforcement of the sentence might be encumbered or impossible.

As can be seen from the definition of securing a claim, the initial application for securing of the claim is not open to competition of opinions and evidence between the parties in the proceeding, the main reason for which is the protection of the plaintiff's interests if there is a risk of the enforcement of the sentence being impossible or encumbered. Such understanding of the essence of securing of the claim, i.e., to ensure mostly the enforcement of the creditor's interests, has become outdated, as it creates a risk of protection of the defendant's interests under circumstances, when the procedural competition principle is not applied. Due to such circumstances, in order to strengthen and balance the defendant's guarantees against unfounded infringement of his rights, amendments to the Civil Procedure Law entered in effect on April 20, 2021, which supplemented Section 140 of the Law with Paragraph 2.1, which stipulates that in matters when the subject of the matter is a monetary claim and means of securing of the claim are applied in the form of pledging of movable property or cash owned by the defendant, or entering a prohibition note in the register of the relevant movable property or any other public register, or seizure of a ship, or pledging of payments due from third parties, including money in credit institutions and other financial institutions, the plaintiff shall secure the potential damage to the defendant, by paying five percent from the claimed amount into the deposit account of the court bailiff (Civil Procedure Law, 1999). The court or the judge, in making a decision on securing of the claim, may impose an obligation to the plaintiff to secure the potential damage in a higher amount. The court or the judge may fully or partially exempt from securing of the damage, if, taking into account the circumstances of the matter, securing of the damage is not just or proportionate to the financial state of the plaintiff. Similar guarantee of interests of the plaintiff is contained in Paragraph 4 of Section 140.1 of the Civil Procedure Law, by stipulating that the judge may impose an obligation for the plaintiff to secure the damage, which the defendant may incur in relation to application of temporary protection, and to pay a certain amount of money into the deposit account of the court bailiff, or to submit an equal guarantee to the court (Civil Procedure Law, 1999). As can be seen, contrary to the regulation of securing of the claim, the court does not have an obligation to decide on securing of the potential damage of the defendant in relation to application of means of temporary protection, but at the same time the securing of damage may take place both by a monetary deposit and other similar guarantee, which is not possible in the case of securing of the claim.

Pursuant to Paragraph 6.1 of Section 140 of the Civil Procedure Law, the defendant has to prove the amount of the actual damage to receive the deposited amount for securing of damage and/or, pursuant to Section 143 of the Civil Procedure Law, claim reimbursement of damage in separate proceedings, if securing of the claim or temporary protection have been canceled, because the claim was dismissed, left without proceedings or if proceedings have been terminated, because the plaintiff has abandoned the claim or he did not have any claim rights. Therefore, according to the currently applicable regulations, for the defendant to receive reimbursement of damage, where the amount exceeds $5 \%$ of the dismissed claim amount, the defendant shall have to get involved in another proceedings 
with the plaintiff, which not only puts a burden on the judicial system but also places the defendant in an unequal position with the plaintiff whose claim and the securing of the claim have been declared unfounded.

If the defendant believes the applied securing of the claim or temporary protection to be unfounded, then pursuant to Paragraph 5 of Section 140 of the Civil Procedure Law and Paragraph 7 of Section 140.1, in order to cancel the securing of the claim or temporary protection, the defendant shall address the same court that has passed this judgment and that shall have to decide on this application of the defendant at a court hearing (Civil Procedure Law, 1999). Pursuant to Paragraph 1 of Section 141 of the Civil Procedure Law, the defendant may file an ancillary complaint only if the application for securing of the claim or temporary protection has been dismissed. As can be seen, the procedure of cancellation of securing of the claim takes a lot more time, since it provides for consideration of the defendant's application at the court hearing, after which a certain amount of time may be taken by consideration of the ancillary complaint in the court of appeal, which is not a justified solution in terms of procedural economy or respecting the equality of the parties.

The fact that as of the moment of entering in effect of the Civil Procedure Law the legal norms of the institute of securing of the claim had been amended sixteen times, does not cause conclusion that the efficiency of this legal institute has improved, which fails to help strengthen the legal understanding and public trust in the judicial system, which in general harms the long-term development of the society. In its audit report of June 5, 2017 "Have the measures of development of the judicial system encouraged efficiency of the courts" (Audit report, 2017), the State Audit Office has concluded that "unfortunately, the research of the public organizations and public surveys in Latvia still show that less than half of the Latvian population trusts in the judicial system. The population believes that the most important issue in the Latvian judicial system is the long terms for adjudication of the cases. Violations of the professional activities and ethics of judges, insufficient quality of court judgments, significant number of pending cases, etc. are also relatively often mentioned as significant problems in the Latvian judicial system". No doubt any member of Latvian society has faced similar problems, when filing an application for securing of a claim to the court or a petition to cancel the applied securing of the claim, which causes and increases public distrust of the institute of securing of the claim, sometimes rightly believing that the institute of securing of the claim is inefficient, expensive and of poor quality, which undoubtedly has a negative impact on legal stability and the long-term development of society.

\section{Conclusions}

As a result of this research the author has made the following conclusions:

1) Latvia is not sufficiently using successful procedural solutions for securing of the claim that have been used in other countries, which may make the legal framework of securing of the claim more modern and efficient, thus strengthening the guarantee of the person's rights to just court.

2) The Latvian legal policy planning, where only ten years after the Civil Procedure Law entered in effect it became clear that Latvia is the only country in the European Union, 
which lacks comprehensive regulation of temporary protection in legal civil disputes, cannot be called successful and efficient, which has adverse effect on the sustainable development of the society, when each member of the society feel confident of the protection of his rights.

3) There are very few in-depth scientific studies in Latvia on the issue of civil procedure in general and on the issue of securing of the claim in particular. The main findings on the application of securing of the claim in court judgments, which also support the prevailing opinion in Latvian jurisprudence on the securing of the claims, are based on the findings of legal scholars of the last century. This situation leads to stagnation in the long-term development of this law institute, which affects the frequent changes and quality of the legal framework, which in turn plays an important role in the sustainable development of society.

4) Improvement of the legal framework of securing of the claim and temporary protection should be done in the direction of strengthening proportionality of the interests of the plaintiff and the defendant, by including more clear criteria for application or cancellation of means of securing of the claim and temporary protection, reimbursement of damage of the defendant, resulting from unfounded application of securing of the claim and temporary protection, thus balancing the interests of the parties in the proceedings with the rights to just court. Leaving the decision on securing or rejecting the claim only in the legal feelings of the judge, because the law does not contain objective criteria when the claim is to be secured or the request for securing to be rejected, does not achieve the purpose of securing of the claim or temporary protection - temporary settlement of the dispute, to save the enforcement of the infringed rights of the plaintiff by restricting the rights of the defendant.

5) It should be necessary to improve a legal framework for the possibility to ask the court to secure the claim, if it is essentially planned to be filed with the court of another state, including a court of a member state of European Union, thus making the Latvian Civil Procedure Law more modern and competitive, which will make Latvia's business environment attractive to investors, which, in turn, would make a significant contribution to Latvia's economic growth and sustainable development.

6) Latvian population considers the long terms for adjudication of the cases to be the most significant problem in the Latvian court system, as a result of which the principle of procedural economy should be strengthened in the legal regulation of securing of the claim and temporary protection, ensuring that matters of securing of the claim or cancellation thereof should be adjudicated in an urgent proceeding and allowing the courts to adjudicate these matters in written proceedings, holding court hearings only if objectively necessary or if the parties so request. Such a strengthening of the principle of procedural economy would improve public confidence in the judiciary, which is a key factor in the sustainable development of society and the strengthening of democratic values.

\section{References}

Annotation of the amendments to the Civil Procedure Law (2021). Grozijumi Civilprocesa likumā. Latvijas Republikas likums. Stājas spēkā 20.04.2021. Publicēts: Latvijas Vēstnesis, 65A, 06.04.2021. Retrieved from:http:/ / titania.saeima.lv/LIVS13/SaeimaLIVS13.nsf/0/7124D67541E6AF94C225851A0033 211A?OpenDocument 
Augstākās tiesas Senāta Civillietu departamenta 2011. gada 6. aprịla lēmums lietā Nr. SKC -951/2011. Retrieved from https://www.at.gov.lv/lv/tiesu-prakse/judikaturas-nolemumu- arhivs/civillietudepartaments/hronologiska-seciba?lawfilter $=0$ \&year $=2011$

Audit report (2017). Audit report No.2.4.1-11/2016, June 5, 2017. State Audit Office of the Republic of Latvia. Retrieved from: https://lrvk.gov.lv/lv/revizijas/revizijas/noslegtas-revizijas/tiesu-iekartasattistibas-ietvaros-laika- no-2009-lidz-2015gadam-istenoto-pasakumu-efektivitate

Baumbach, A., Lauterbach, W., Albers, J., Hartmann, P. (2007) 'Kommentar zur ZPO”. 65 Auflage. Munchen, 2007.

Bukovskis, V. (1933) "Civīlprocesa mācības grāmata". Rīga: Autora izdevums.

Civil Procedure Law. Law of the Republic of Latvia. Entry into force 01.03.1999. Published in: 03.11.1998. "Latvijas Vēstnesis" Nr.326/330. Retrieved from https://likumi.lv/ta/en/en/id/50500-civilprocedure-law

Convention for the Protection of Human Rights and Fundamental Freedoms. International convention. Adoption 04.01.1950. Retrieved from https://likumi.lv/ta/en/starptautiskie-ligumi/id/649convention-for-the-protection-of-human-rights-and-fundamental-freedoms

ECHR Judgement (2006). Case of "Borshchevskiy v Russia". Application No. 14853/03, Retrieved from https://hudoc.echr.coe.int/eng\#\{\%22fulltext $\% 22:[\% 22$ Borshchevskiy $\% 20 \mathrm{v} \% 20$ Russia $\% 22], \% 22$ documentcollectionid2\%22:[\%22GRANDCHAMBER\%22,\%22CHAMBER\%22],\%22itemid\%22 $:[\% 22001-76964 \% 22]\}$

Esser, J. (1970 ) "Vorverstandnis und Methodenwahl in der Rechtsfindung". Frankfurt am Main: Athenaum Verlag GmbH, 1970.

Insolvency Law. Law of the Republic of Latvia. Entry into force 01.11.2010. Published in: Latvijas Vēstnesis, 124, 06.08.2010. Retrieved from https://likumi.lv/ta/en/en/id/214590-insolvency-law

Kant, I. (1796) "Psilosophy of law". Retrieved from: https://oll-resources.s3.us-east2.amazonaws.com/oll3/store/titles/359/Kant_0139_EBk_v6.0.pdf

Konradi, F., Zvejnieks, T. ( 1939. ). Civilprocesa likums ar paskaidrojumiem, izvilkumiem no Latvijas Senāta un Tiesu Palātas spriedumiem un no attiecīgās zinātniskās literatūras, kā arī dažiem aizrādījumiem uz likumdošanas motīviem. Rīga., Valsts Tipogrāfija.

LPSR Civilprocesa kodekss. LPSR likums. Apstiprināts 1963.gada 27.decembrī. Publicēts Augstākā Padomes un Valdības Ziņotājāa, 1964, Nr.1.

Ministry of Justice of the Republic of Latvia (2018). Tieslietu ministrijas darbības stratēgija 2018-2020.gadiem. Retrieved from: https://www.tm.gov.lv/lv/ministrija/ricibas-plans-vadibas-dokumenti/tieslietuministrijas-darbibas-strategija

Pētersone, Z.(2010) "Civiltiesiskās aizsardzības līdzeklị, kas tiesā piemērojami intelektuālā ìpašuma tiesību lietās". Retrieved from https://www.lu.lv/fileadmin/user_upload/lu_portal/zinas/ZanePetersone.pdf

Radbruch, G. ( 1964 ) ' Einführung in die Rechtswissenschaft ". Publisher: Koehler. Published: 1964

Rozenbergs, J., Briǵis, I. ( 1978) "Padomju civilprocesuālās tiesības". Rīga: "Zvaigzne".

The Civil Law. Law of the Republic of Latvia. Entry into force 01.09.1992. Published in: Valdỉbas Vēstnesis, 41, 20.02.1937. Retrieved from https://likumi.lv/ta/en/en/id/225418-the-civil-law

The Constitution of the Republic of Latvia. Entry into force 07.11.1922. Published in: Latvijas Vēstnesis, 43, 01.07.1993. Retrieved from https://likumi.lv/ta/en/en/id/57980-the-constitution-of-the-republicof-latvia 